\title{
REFINING ALUMINIUM-ALLOY MELTS WITH GRAPHITE ROTORS
}

\author{
UPORABA GRAFITNIH ROTORJEV ZA REFINACIJO TALIN IZ \\ ZLITIN NA OSNOVI ALUMINIJA
}

\author{
Petr Lichý1, Markéta Bajerová ${ }^{2}$ Ivana Kroupová1, Tomáš Obzina ${ }^{1}$ \\ ${ }^{1}$ VŠB - Technical University of Ostrava, Faculty of Materials Science and Technology, Department of Metallurgy and Foundry, 17. listopadu \\ 2172/15, 70800 Ostrava-Poruba, Czech Republic \\ 2JAP Industries s.r.o., Bystřice 1260, 73995 Bystřice, Czech Republic
}

Prejem rokopisa - received: 2019-07-12; sprejem za objavo - accepted for publication: 2019-11-08

doi:10.17222/mit.2019.147

\begin{abstract}
The presented paper is focused on the study of refining aluminium-alloy melts. The quality of castings is determined by the basic material, i.e., the input material (furnace charge), its subsequent melting and subsequent metallurgical modifications. To allow the profitability of production, low-quality input materials are currently used, which, although they have the required chemical composition, may contain a large amount of impurities, coming not only from the original input materials, but also from their processing. To allow a cost reduction, in addition to rejected castings, the residues of gating and chipping from the machining are used as charge materials in foundries. However, the melt thus prepared is heavily contaminated with gases and inclusions. The aim of the research was, therefore, to verify the use of graphite rotors functioning as degassing units for refining aluminium melts. The experiments were conducted under laboratory and pilot-plant conditions using the plant equipment. The refining efficiency was monitored with respect to the type and shape of the graphite rotor and the refining medium used. The achieved purity of the resulting melt was evaluated to establish the density index and the final cast microstructure.

Keywords: aluminium alloy, degassing, microstructure, density index
\end{abstract}

Članek opisuje rafinacijo talin iz Al zlitin. Kvaliteta ulitkov je odvisna od osnovnega materiala (sestave, čistosti itd.), postopka taljenja in metalurških modifikacij. S pridobitvenega stališča proizvodnje se trenutno uporabljajo manj kakovostni vhodni materiali, ki sicer ustrezajo glede zahtevane osnovne kemijske sestave, vendar lahko vsebujejo veliko nečistoč. Te se ni nujno, da nahajao $\mathrm{v}$ originalnem izhodnem materialu, lahko pa nastajajo tudi med samim proizvodnim procesom. Zaradi zmanjšanja stroškov se v livarnah kot vložek uporabljajo tudi s strani kontrole zavrnjeni ulitki (izmet) in ostanki mehanske obdelave (odrezki, ostružki). Zaradi tega je pripravljena Al talina močno kontaminirana s plini in nekovinskimi vključki. Cilj avtorjev pričujoče raziskave je bil verificirati rafinacijo Al talin z uporabo grafitnih rotorjev v enotah za razplinjevanje. Preizkuse so izvajali na laboratorijskih in pilotnih napravah. Učinkovitost rafinacije so zasledovali glede na tip in obliko izbranega grafitnega rotorja in uporabljeno rafinacijsko sredstvo. Doseženo čistost talin so ovrednotili z določanjem indeksa gostote (naprava Dichte Index) in analizo končne mikrostrukture ulitkov.

Ključne besede: zlitina na osnovi aluminija, razplinjanje, mikrostruktura, indeks gostote

\section{INTRODUCTION}

One of the most important steps in the production of aluminium-alloy castings is the preparation of the liquid metal. Pigs with the required chemical composition and residues (especially the remains of the gating including risers and mismatched castings) are used as the input materials. Many foundries also add drillings left after the machining of aluminium castings but these are very heavily contaminated with organic compounds (e.g., residues of oily emulsions). Due to economic requirements, these contaminated materials together with lower-quality input materials (aluminium scrap) are used more and more. This then leads to subsequent problems, which include an increased degree of gassing of the melt, a higher proportion of inclusions and related waste casting rate. ${ }^{1}$ This situation then requires the use of a more efficient method of refining the melt. Still, the most

*Corresponding author's e-mail:

petr.lichy@vsb.cz (Petr Lichý) commonly used way of refining is the use of the refining equipment whose most important part is the refining rotor. It is most often made of silicon carbide or graphite. Graphite rotors are characterized by a low price, high strength and resistance to temperature changes.

The use of the refining equipment should be based on an assumption that the entire refining process, i.e., the elimination of gas and inclusions from the melt, should be as fast as possible, but also as effective as possible, in order to avoid unnecessary downtimes in production. From the point of view of energy loss, this fact is very important, too.

\section{EXPERIMENTAL PART}

The practical part of the study deals with comparing the efficiency of the degassing of chosen types of rotors using nitrogen as the degassing medium. Two rotors from the company JAP INDUSTRIES s.r.o. (Ltd.) 

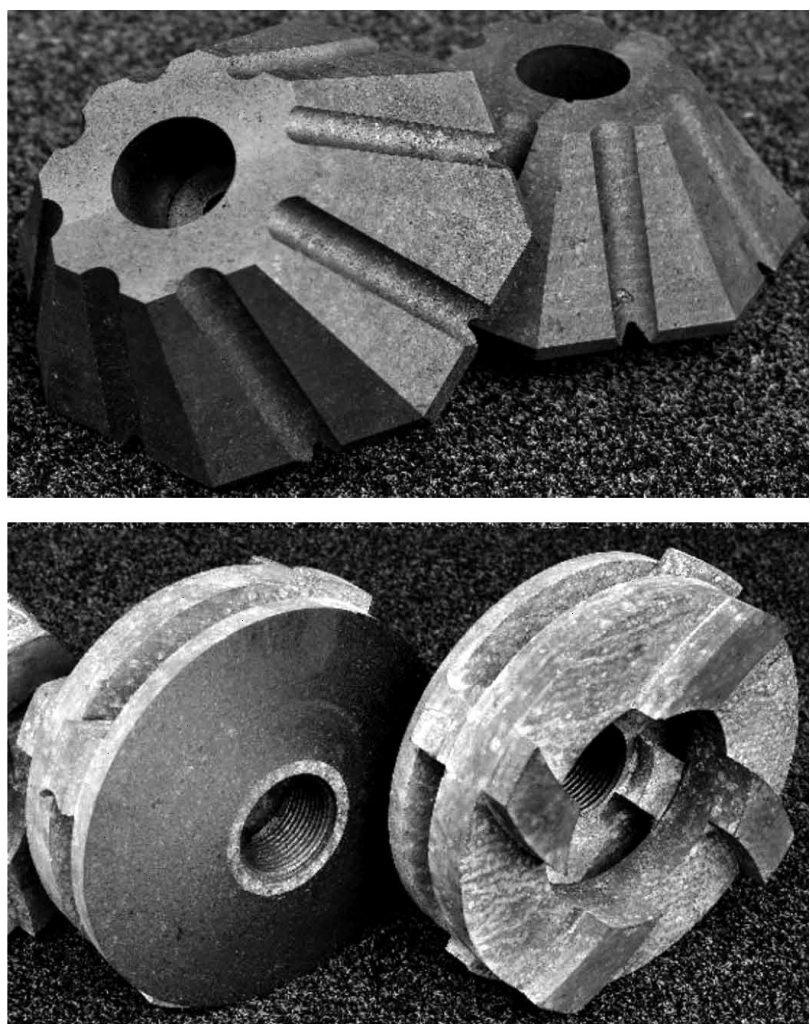

Figure 1: Used graphite rotors (J8 - left, F2A - right)

marked as J8 and F2A (Figure 1) were tested at $500 \mathrm{~min}^{-1}$.

Both rotors were tested with the AlSi7Mg0.3 alloy. ${ }^{2}$ The flow rate of the degassing medium was $10.5 \mathrm{~L} / \mathrm{min}$, the melt temperature $710{ }^{\circ} \mathrm{C}$, the ambient temperature $21{ }^{\circ} \mathrm{C}$ and air humidity of $28 \%$. The rotor was located in the melt $150 \mathrm{~mm}$ above the crucible bottom. The cycle for evaluating the refining effectiveness is given in Table 1. After each step, the samples were taken (marked with $\mathrm{J}$ for the $\mathrm{J} 8$ rotor and marked with $\mathrm{F}$ for the F2A rotor) and evaluated for purity with respect to their microstructure and density index (DI). The DI is the

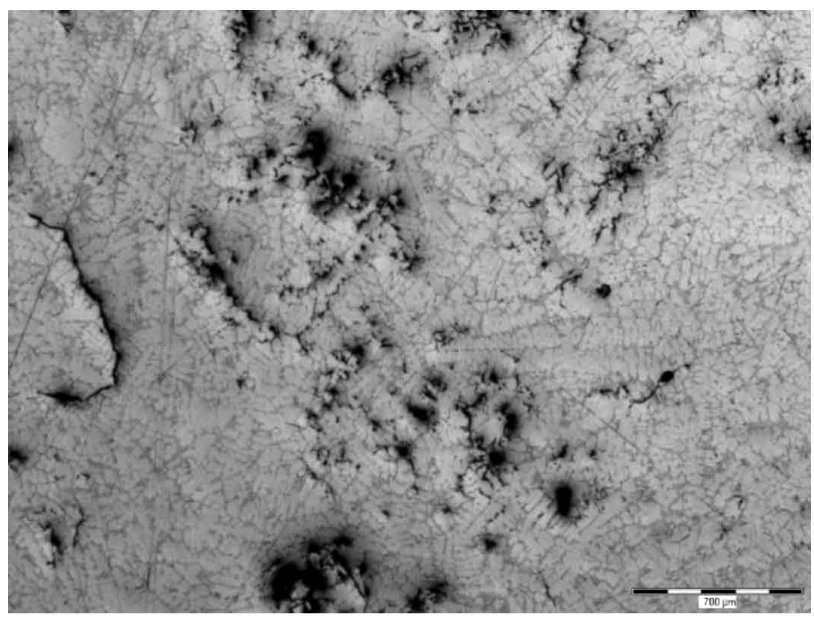

Figure 2: Microstructure of the J1 sample number characteristic for the melt quality of an aluminium melt sample. ${ }^{3}$ The melt-sample pair densities - the one resulting from the vacuum-density test $\left(D_{80 \mathrm{mbar}}\right)$ and the one resulting from the hardening under atmospheric pressure $\left(D_{\text {atm }}\right)$ - are related to each other based on Equation (1).

$$
D I=\left(\left(D_{\text {atm }}-D_{80 \mathrm{mbar}}\right) / D_{\mathrm{atm}}\right) * 100[\%]
$$

Table 1: Test refining cycle

\begin{tabular}{|c|c|c|c|c|}
\hline \multirow[b]{2}{*}{ Order } & \multirow[b]{2}{*}{ Step } & \multirow{2}{*}{$\begin{array}{c}\text { Operation } \\
\text { time } \\
\text { (min) }\end{array}$} & \multicolumn{2}{|c|}{ Sample markings } \\
\hline & & & $\begin{array}{c}\text { Rotor } \\
\text { J8 }\end{array}$ & $\begin{array}{c}\text { Rotor } \\
\text { F2A }\end{array}$ \\
\hline 1 & After melting & - & $\mathrm{J} 1$ & $\mathrm{~F} 1$ \\
\hline 2 & Refining with $\mathrm{N}_{2}$ & 3 & $\mathrm{~J} 2$ & $\mathrm{~F} 2$ \\
\hline 3 & Gassing with $\mathrm{H}_{2}+\mathrm{N}_{2}$ & 6 & $\mathrm{~J} 3$ & F3 \\
\hline 4 & Refining with $\mathrm{N}_{2}$ & 6 & $\mathrm{~J} 4$ & $\mathrm{~F} 4$ \\
\hline 5 & Gassing with $\mathrm{H}_{2}+\mathrm{N}_{2}$ & 6 & J5 & F5 \\
\hline 6 & Refining with $\mathrm{N}_{2}$ & 3 & J6 & F6 \\
\hline 7 & Gassing with air & 5 & $\mathrm{~J} 7$ & F7 \\
\hline 8 & Refining with $\mathrm{N}_{2}$ & 6 & J8 & F8 \\
\hline 9 & Gassing with air & 5 & J9 & F9 \\
\hline 10 & Refining with $\mathrm{N}_{2}$ & 3 & $\mathrm{~J} 10$ & F10 \\
\hline 11 & Gassing with $\mathrm{H}_{2}+\mathrm{N}_{2}$ & 5 & J11 & F11 \\
\hline
\end{tabular}

\section{RESULTS}

The microstructures of the samples ( J1 and J2) obtained with the use of rotor J8 is shown in Figure 2 (sample J1) and Figure 3 (sample J2). It is evident from the figures that in the case of the refining cycle lasting 3 min there is a significant clean-up of the melt.

The values of gassing the melt obtained by evaluating the DI are given for individual samples in Figure 4.

\section{DISCUSSION}

With respect to the final value after the $10^{\text {th }}$ step, both types of rotor showed virtually the same efficiency. However, with respect to the shortest possible time of

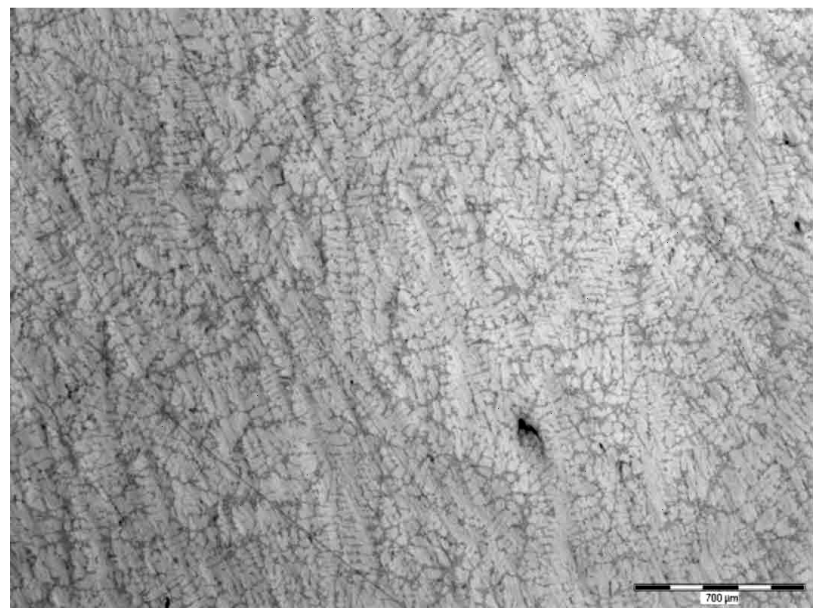

Figure 3: Microstructure of the J2 sample 


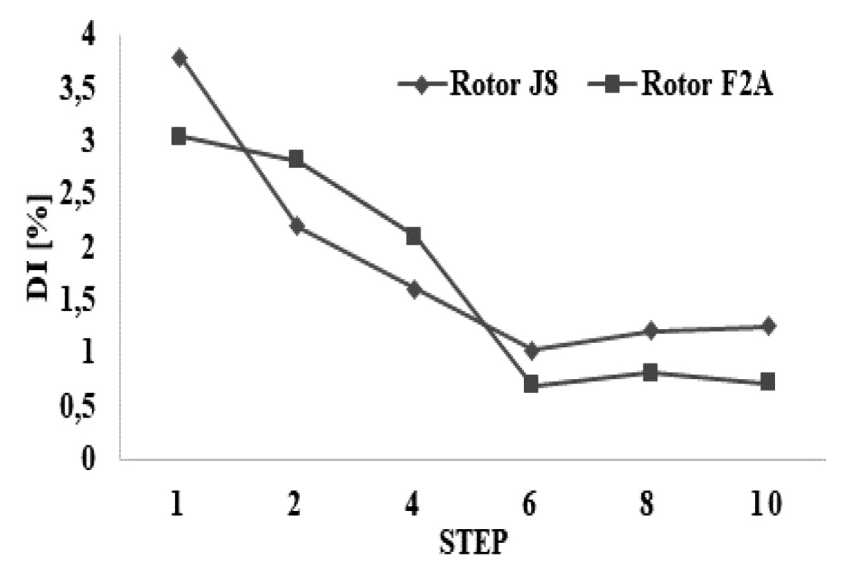

Figure 4: DI determined in relation to the refining step and rotor type

reaching the lowest DI value there is a noticeable difference. The $\mathrm{J} 8$ rotor was more efficient because after the first refining lasting $3 \mathrm{~min}$, the DI value was reduced by $42 \%$, whereas for the F2A rotor, this reduction amounted to only $7 \%$.

\section{CONCLUSIONS}

Achieving a high quality of cast parts made of aluminium alloys is conditioned, inter alia, by the reduction of the hydrogen content. With regard to the production efficiency, it is thus important to achieve this state in the shortest possible time. When comparing the selected rotors, the $\mathrm{J} 8$ rotor meets this condition. The use of appropriate types of rotors in combination with inert gases (argon and nitrogen) will allow us in future to reduce the amount of refining salts, thus eliminating the economic and ecological burdens of foundry plants.

\section{Acknowledgment}

The contribution was worked out with the support of the project MPO TRIO FV 10080 and the support of the projects within "the Student Grant Competition", with numbers SP2020/39 and SP2020/64.

\section{REFERENCES}

${ }^{1}$ M. Cagala, M. Bruska, P. Lichy, J. Beno, N. Špirutová, Influence of Aluminium-Alloy Remelting on The Structure and Mechanical Properties, Mater. Tehnol., 47 (2013) 2, 239-243

${ }^{2}$ R. Pastirčák, J. Ščury, Effect of Pressure on the Crystallisation of AlSi7Mg Alloy, Arch. Metall. Mater., 62 (2017) 4, 2193-2198, doi:10.1515/amm-2017-0323

${ }^{3}$ E. Czekaj, J. Nykiel, Z. Kwak, A. Garbacz-Klempka, M. Nykiel, The Influence of Selected Refining Methods of AlSi7Mg0.3 Silumin on its Quality Index, Archives of Foundry Engineering, 18 (2018) 2, 72-78, doi: $10.24425 / 122505$ 